\title{
Platelet function in hairy-cell leukaemia
}

\author{
M. ZUZEL 1 , J. C. CAWLEY 1 , R. C. PATON 1 , G. F. BURNS ${ }^{2}$, AND G. P. MCNICOL
}

From the ${ }^{1}$ University Department of Medicine, General Infirmary at Leeds, and the ${ }^{2}$ Department of Haematological Medicine, University of Cambridge, UK

S'JMMARY A quantitative study of various aspects of platelet function was carried out in eight patients with typical hairy-cell leukaemia (HCL). In at least two patients platelet aggregation was convincingly reduced to more than one aggregating agent (ADP, adrenaline, collagen, thrombin, and ristocetin). Granular storage capacity for $\left\{{ }^{14} \mathrm{C}\right\}$ 5-HT was reduced in five of the six patients tested. The two patients with definitely abnormal aggregation had the greatest reduction in granular storage pool and the longest bleeding times of those tested but, like the other patients, they did not have a clinical haemostatic defect. It was concluded that a granular storage pool defect (SPD) was at least partly responsible for aggregation abnormalities in HCL since the platelet release reaction in response to thrombin appeared to be normal. All our patients ran a chronic course uncomplicated by any of the factors known to predispose to a platelet SPD acquired in the circulation. Although in the one patient tested before and after splenectomy there was some improvement in platelet aggregation after operation, there was no clear general relationship between defective platelet function and either previous splenectomy or platelet count. Since a direct involvement of the megakaryocytic series in the underlying cell proliferation of HCL seems unlikely, it is concluded that the platelet defect can most reasonably be attributed to the production of abnormal platelets as a result of marrow fibrosis and/or infiltration by hairy cells.

Hairy-cell leukaemia (HCL) is now widely recognised as a distinct clinicopathological entity in which characteristic mononuclear cells, hairy cells, circulate in varying numbers and infiltrate a variety of organs, especially the bone marrow and spleen (Bouroncle et al., 1958; Katayama and Finkel, 1974; Catovsky, 1977; Golomb, 1978). Thrombocytopenia is one of the most consistent findings in the disease (Catovsky, 1977; Jansen et al., 1978; Sebahoun et al., 1978). In addition, there have been brief reports of qualitative abnormalities of platelets in HCL (Levine and Katayama, 1975; Golomb et al., 1978; Feiner et al., 1978).

In the present paper, in an attempt to characterise further the nature of the platelet abnormality in the disease, we report a detailed study of platelet function in eight patients with typical HCL.

\section{Patients, materials, and methods}

PATIENTS AND CONTROLS Eight patients with HCL were studied. All fulfilled the clinical and haematological criteria of $\mathrm{HCL}$

Received for publication 7 February 1979
(Burns et al., 1978). Relevant clinical and haematological data are included in Table 1. Six of the patients had had no recent drug therapy, while two (HD and FB, Tables 1 and 2) were on $5 \mathrm{mg} /$ day of prednisone. In four patients the spleen had been removed before study. Four patients had not been splenectomised, and one of these (AF) was also studied on two occasions after splenectomy. On each occasion of testing, a healthy young member of the clinical staff donated control blood. For three HCL patients (HD, FB, AF) blood was transported some distance (up to 3 hours' travelling time) before platelet separation and testing; in each instance control blood was taken at the same time and transported in a similar way.

PLATELET SEPARATION

Platelet-rich plasma (PRP) was prepared from citrated blood (1 vol $3 \cdot 8 \%$ tri-sodium citrate to $9 \mathrm{vol}$ of blood) by centrifugation (10 minutes at $250 \mathrm{~g}$ (max) at room temperature). The platelet count in PRP was estimated visually (Brecher and Cronkite, 1950) and electronically (Thrombocounter, Coulter Electronics). Visual counts were performed on PRP diluted with $4 \%$ formol-saline, and contamination with other cell types was noted. Hairy-cell con814 
Platelet function in hairy cell leukaemia

Table 1 HCL: some haematological data and ADP-induced platelet aggregation

\begin{tabular}{|c|c|c|c|c|c|c|c|c|c|c|c|}
\hline \multirow[t]{3}{*}{ Patient } & \multirow[t]{3}{*}{ Splenectomy } & \multirow{3}{*}{$\begin{array}{l}W B C \\
\left(\times 10^{\circ} / l\right)\end{array}$} & \multirow{3}{*}{$\begin{array}{l}\text { Platelets } \\
\left(\times 10^{\circ} / I\right)\end{array}$} & \multirow{3}{*}{$\begin{array}{l}\text { Bleeding } \\
\text { time } \\
(\text { min })\end{array}$} & \multirow{3}{*}{$\begin{array}{l}P R P \\
\text { platelets } \\
\left(\times 10^{\circ} / l\right)\end{array}$} & \multicolumn{6}{|l|}{$A D P$} \\
\hline & & & & & & \multicolumn{2}{|l|}{ Patient } & \multicolumn{2}{|l|}{ Control } & \multicolumn{2}{|c|}{$\%$ Control } \\
\hline & & & & & & $\underset{(\mu M A D P)}{K m}$ & $\begin{array}{l}V \max \\
(\mathrm{cm} / \min )\end{array}$ & $\begin{array}{l}K m \\
(\mu M A D P)\end{array}$ & $\begin{array}{l}V \max \\
(\mathrm{cm} / \mathrm{min})\end{array}$ & $K m$ & $V \max$ \\
\hline PS & $+18 \mathrm{mth}$ & $7 \cdot 1$ & 270 & 5 & 300 & - * & - & - & - & - & - \\
\hline LH & $+16 \mathrm{mth}$ & $4 \cdot 2$ & 300 & $3 \cdot 5$ & 300 & $1 \cdot 06$ & 31 & $0 \cdot 75$ & 29 & 141 & 107 \\
\hline FW & $+46 \mathrm{mth}$ & $4 \cdot 1$ & 225 & 7 & 142 & $1 \cdot 11$ & $10 \cdot 5$ & $0 \cdot 74$ & $12 \cdot 1$ & 150 & 87 \\
\hline AB & $+8 \mathrm{mth}$ & $4 \cdot 9$ & 130 & $5 \cdot 5$ & 200 & $0 \cdot 71$ & $17 \cdot 2$ & 0.6 & $17 \cdot 2$ & 118 & 100 \\
\hline HD & No & $2 \cdot 1$ & 71 & ND & 134 & 0.64 & $14 \cdot 4$ & $1 \cdot 12$ & $19 \cdot 2$ & 57 & 75 \\
\hline FB十 & No & $4 \cdot 0$ & 40 & ND & 96 & $7 \cdot 1$ & $13 \cdot 1$ & $3 \cdot 5$ & $11 \cdot 6$ & 203 & 112 \\
\hline WE & No & $12 \cdot 7$ & 150 & 15 & 90 & 0.60 & $22 \cdot 2$ & $1 \cdot 42$ & 25 & 42 & 88 \\
\hline AF (a) & -1 wk & $3 \cdot 3$ & 50 & 8 & 94 & $1 \cdot 5$ & $4 \cdot 5$ & $1 \cdot 4$ & $18 \cdot 5$ & 107 & 24 \\
\hline (b) & +1 wk & $4 \cdot 5$ & 80 & ND & 111 & 0.42 & $12 \cdot 8$ & $1 \cdot 3$ & $15 \cdot 4$ & 32 & 83 \\
\hline (c) & $+3 \mathrm{mth}$ & $15 \cdot 6$ & 140 & ND & $70 \ddagger$ & 0.62 & $12 \cdot 1$ & $2 \cdot 4$ & $15 \cdot 4$ & 26 & 78 \\
\hline
\end{tabular}

*Full dose-response not tested, but at $5 \mu \mathrm{M}$ ADP: aggregation rate $81 \%$ control; aggregation maximum $100 \%$ control.

ND $=$ not done.

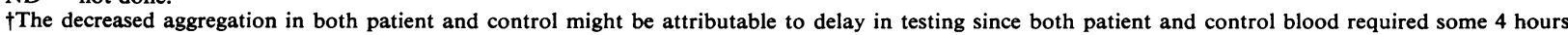
for transport to the laboratory.

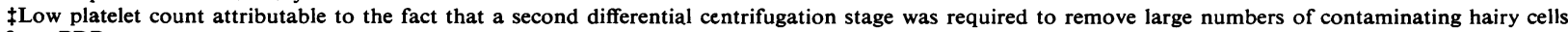
from PRP.

tamination was negligible except in one instance (FB, Table 1) where contaminating hairy cells were removed by further differential centrifugation. Some red blood cell (RBC) contamination was observed, especially in anaemic and thrombocytopenic patients, but this was always less than $10 \%$ of the total cell count in PRP. Attempts to remove these RBCs by centrifugation always resulted in significant loss of platelets. Therefore, these low levels of RBC contamination were tolerated in platelet functional studies and taken into account in calculations of total platelet protein (see Results). In all instances, control PRP was diluted with autologous plateletpoor plasma (PPP) to bring the platelet count to that of patient PRP. During the course of experimentation, PRP was kept at room temperature in plastic containers sealed with parafilm; under such conditions platelet aggregation did not change significantly over the time intervals involved (up to 6 hours from blood withdrawal).

PLATELET AGGREGATION

Aggregation was measured turbidimetrically in 1-ml samples of PRP with a Born Mk III aggregometer. For each PRP sample, the sensitivity of the recording was set so that PRP and PPP corresponded to $10 \%$ and $100 \%$ light transmission respectively. For ADP-induced aggregation, a chart speed of 12 $\mathrm{cm} / \mathrm{min}$ was employed; for all other agents, a chart speed of $3 \mathrm{~cm} / \mathrm{min}$ was used.

\section{$A D P$}

The rate of ADP-induced aggregation was measured by drawing a straight line through the linear part of the trace. A wide range of final concentrations of
ADP $(0 \cdot 5-20 \mu \mathrm{M})$ were used to obtain a range yielding a linear dose-response on a double reciprocal plot (Skoza et al., 1967); the intercepts with the vertical and horizontal axes were used to read off the Vmax and $\mathrm{Km}$ respectively. (Vmax, theoretical maximal rate of aggregation at infinite ADP concentration; $\mathrm{Km}$, the concentration of ADP causing half maximal aggregation).

\section{Collagen}

Collagen (Hormon-Chemie, Munich) was used at final concentrations of $2-5 \mu \mathrm{g} / \mathrm{ml}$ PRP; at these low concentrations resulting aggregation is probably dependent largely on platelet ADP release. The lag time (the time between addition of collagen and the onset of aggregation) was measured in seconds. The aggregation rate $(\mathrm{cm} / \mathrm{min})$ was estimated from the linear part of the trace, and the maximum aggregation (Tmax) measured as per cent increase in light transmission.

\section{Adrenaline}

Adrenaline (Sigma) was used at concentrations in PRP of 5-50 $\mu \mathrm{M}$. Aggregation rate $(\mathrm{cm} / \mathrm{min})$ was measured, and the presence or absence of releasedependent secondary increase in light transmission was noted.

\section{Ristocetin}

Ristocetin (Lundbeck, Copenhagen) was used at a final concentration of $1-1.5 \mathrm{mg} / \mathrm{ml}$ PRP, and the rate of increase of light transmission was measured from the early linear part of the trace. No clear distinction was possible between agglutination and release-dependent aggregation. 


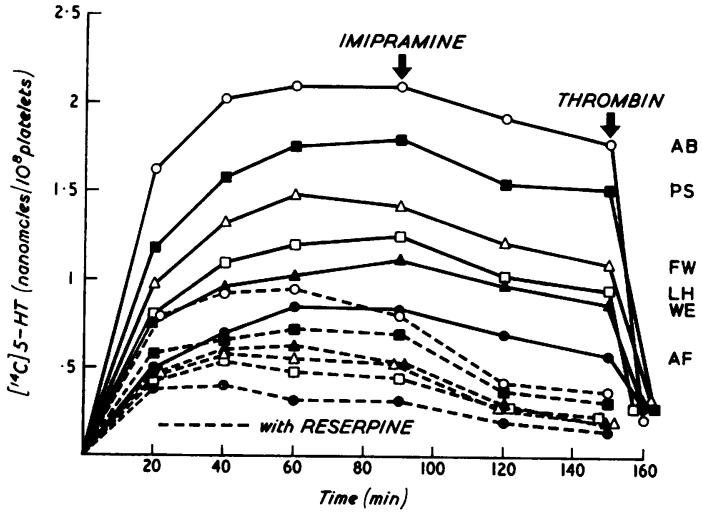

(a)

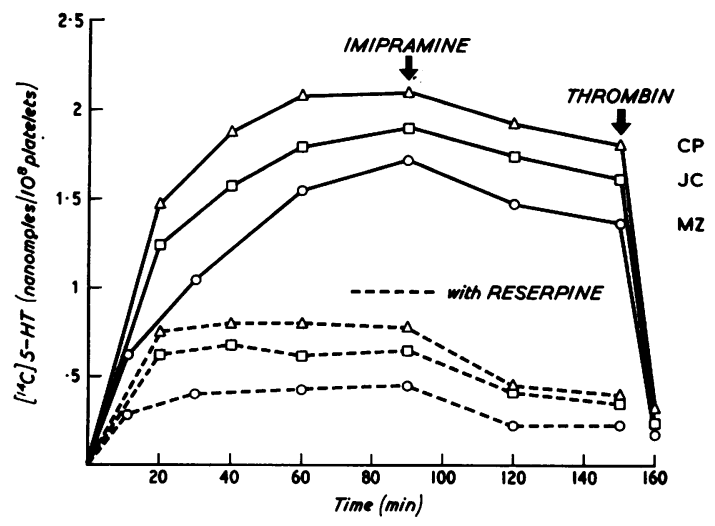

(b)

Fig. 1 Uptake, storage, and release of labelled 5-HT (a) patients, (b) controls. Reserpine was added at a final concentration of $2 \mu \mathrm{M} 30 \mathrm{~min}$ before addition of $\left\{2-{ }^{14} \mathrm{C}\right\} 5-\mathrm{HT}\left(2.5 \mathrm{nmol} / 10^{8}\right.$ platelets $)$ at time 0.

Imipramine was used at a final concentration of $20 \mu \mathrm{M}$. Thrombin was added to a final concentration of 5 NIH U/ml PRP, together with $250 \mathrm{U}$ of streptokinase ( final concentration) in order to lyse clots. Addition of streptokinase only produced no release of platelet radioactivity.

\section{Thrombin}

Bovine topical thrombin (Parke Davis, Detroit) was used at a final concentration of $0.2 \mathrm{NIH} \mathrm{U/ml} \mathrm{PRP,}$ and the rate of aggregation was measured.

ACCUMULAtion, STORAGE, AND RELEASE OF 5-H T

PRP was incubated at $37^{\circ} \mathrm{C}$ with $\{2-14 \mathrm{C}\}$ 5-HT creatinine sulphate (Radiochemical Centre, Amersham; specific activity $50 \mathrm{mCi} / \mathrm{mmol}$ ) at a final concentration of $2 \cdot 5 \mathrm{nmol} / 10^{8}$ platelets. As is demonstrated in Fig. 1, this amount of 5-HT is in slight excess of that $\left(\bumpeq 2 \mathrm{nmol} / 10^{8}\right.$ platelets) which normal human platelets accumulated under these experimental conditions. Furthermore, this amount of labelled 5-HT is approximately 10 times that of the endogenous 5-HT of human platelets (Hardisty et al., 1972); endogenous 5-HT was therefore ignored in our calculations of 5-HT storage capacity (see Results).

At regular intervals, duplicate aliquots of PRP were removed, centrifuged for 1 minute at $12000 \mathrm{~g}$ at room temperature, and the radioactivity in $100 \mu \mathrm{l}$ of supernatant was counted by using diatol scintillant (Herberg, 1960) and a Packard tri-carb liquid scintillation spectrometer model 3390 . The platelet uptake of 5-HT was calculated by subtracting the supernatant count from the total PRP radioactivity, and the result was expressed in nmol 5-HT (and metabolites) $/ 10^{8}$ platelets. Before addition of $5-\mathrm{HT}$, PRP was preincubated for 30 minutes at $37^{\circ} \mathrm{C}$ in the presence or absence of reserpine (Sigma; final concentration $2 \mu \mathrm{M}$ ). After 90 minutes' incubation with 5-HT, imipramine (Sigma; final concentration $20 \mu \mathrm{M}$ ) was added to both the reserpinised and nonreserpinised PRP, and platelet radioactivity was measured for a further 60 minutes. After a total of 160 minutes' incubation with 5-HT, duplicate 0.5-ml samples of PRP were mixed with thrombin ( $5 \mathrm{NIH} \mathrm{U} / \mathrm{ml}$ final concentration) and streptokinase (Kabi; $250 \mathrm{U} / \mathrm{ml}$ final concentration) and incubated at $37^{\circ} \mathrm{C}$ for a further 10 minutes. Release of granule 5-HT from platelets was then estimated from the increased counts in the supernatant of lysed clots.

In order to relate the results to platelet mass in addition to platelet number, total platelet protein was measured in two controls and in the two most abnormal HCL patients (AF and WE) by Lowry's method as modified by Hess et al. (1978).

\section{BLEEDING TIME}

The template bleeding time was performed by means of a disposable spring-loaded device (Simplate, General Diagnostics, New Jersey) according to the method of Mielke et al. (1969).

\section{PLATELET SURVIVAL}

Platelet survival was measured in one patient (WE) with massive splenomegaly $(16 \mathrm{~cm}$ below the left costal margin) by a ${ }^{51} \mathrm{Cr}$ method (Aster and Jandl, 1964). Simultaneously, an attempt was made to label platelets by the intravenous infusion of $50 \mu \mathrm{Ci}$ of $\{2-14 \mathrm{C}\}$ 5-HT (New England Nuclear, Boston, Mass.; specific activity, $50 \mathrm{mCi} / \mathrm{mmol}$ ) (Paton et al., 1979).

\section{ELECTRON MICROSCOPY}

In patient $\mathrm{AF}$, who showed the most striking platelet function abnormalities, the ultrastructure of the 
Table 2 HCL: platelet responses to collagen, adrenaline, and ristocetin

\begin{tabular}{|c|c|c|c|c|c|c|c|c|c|c|c|c|c|c|c|c|c|}
\hline \multirow[t]{3}{*}{ Patient } & \multicolumn{9}{|c|}{ Collagen } & \multicolumn{5}{|l|}{ Adrenaline } & \multicolumn{3}{|c|}{ Ristocetin } \\
\hline & \multicolumn{3}{|c|}{ Patient } & \multicolumn{3}{|c|}{ Control } & \multicolumn{3}{|c|}{$\%$ Control } & \multicolumn{2}{|l|}{ Patient } & \multicolumn{2}{|l|}{ Control } & \multirow{2}{*}{$\begin{array}{l}\% \\
\text { Con- } \\
\text { trol }\end{array}$} & \multirow{2}{*}{$\begin{array}{l}\text { Patient } \\
\text { Rate } \\
(\mathrm{cm} / \mathrm{min})\end{array}$} & \multirow{2}{*}{$\begin{array}{l}\text { Control } \\
\text { Rate } \\
(\mathrm{cm} / \mathrm{min})\end{array}$} & \multirow{2}{*}{$\begin{array}{l}\% \\
\text { Con- } \\
\text { trol }\end{array}$} \\
\hline & $\begin{array}{l}\text { Lag } \\
(s)\end{array}$ & $\begin{array}{l}\text { Rate } \\
(\mathrm{cm} / \mathrm{min})\end{array}$ & $\underset{\%}{T \max }$ & $\begin{array}{l}\text { Lag } \\
(s)\end{array}$ & $\begin{array}{l}\text { Rate } \\
(\mathrm{cm} / \mathrm{min})\end{array}$ & $\underset{\%}{T \max }$ & Lag & Rate & Tmax & $\begin{array}{l}\text { Rate } \\
(\mathrm{cm} / \mathrm{min})\end{array}$ & Release & $\begin{array}{l}\text { Rate } \\
(\mathrm{cm} / \mathrm{min})\end{array}$ & Release & & & & \\
\hline PS & 50 & $10 \cdot 8$ & 50 & 64 & $17 \cdot 5$ & 77 & 78 & 69 & 65 & $5 \cdot 7$ & No & $6 \cdot 8$ & No & 84 & $24 \cdot 5$ & $13 \cdot 7$ & 178 \\
\hline $\mathbf{L H}$ & 40 & $17 \cdot 2$ & 83 & 50 & $14 \cdot 6$ & 86 & 80 & 117 & 97 & $6 \cdot 7$ & No & $6 \cdot 9$ & No & 97 & $7 \cdot 2$ & $10 \cdot 2$ & 70 \\
\hline F W & 70 & $7 \cdot 5$ & 50 & 60 & $6 \cdot 4$ & 44 & 116 & 117 & 113 & $4 \cdot 0$ & Yes & $5 \cdot 0$ & Yes & 80 & $2 \cdot \overline{5}$ & $7 \cdot 4$ & 34 \\
\hline A B & 64 & $5 \cdot 6$ & 30 & 70 & $3 \cdot 7$ & 25 & 91 & 151 & 120 & $5 \cdot 1$ & Yes & $3 \cdot 7$ & Yes & 136 & $4 \cdot 6$ & $3 \cdot 3$ & 139 \\
\hline HD & 100 & $6 \cdot 4$ & 30 & 90 & $5 \cdot 0$ & 21 & 111 & 128 & 143 & $1 \cdot 3$ & Yes & $2 \cdot 1$ & Yes & 61 & $6 \cdot 2$ & $7 \cdot 5$ & 82 \\
\hline FB & 110 & $4 \cdot 2$ & 20 & 88 & $2 \cdot 3$ & 16 & 125 & 182 & 125 & ND & ND & ND & ND & ND & $3 \cdot 4$ & $4 \cdot 4$ & 77 \\
\hline WE & 100 & $6 \cdot 5$ & 20 & 60 & $10 \cdot 8$ & 46 & 160 & 60 & 43 & $2 \cdot 4$ & Yes & $3 \cdot 0$ & Yes & 80 & $2 \cdot 5$ & $10 \cdot 0$ & 25 \\
\hline AF (a) & 100 & 0.8 & 7 & 60 & $6 \cdot 0$ & 28 & 160 & 13 & 25 & $1 \cdot 1$ & No & $2 \cdot 2$ & Yes & 50 & $1 \cdot 8$ & $8 \cdot 5$ & 21 \\
\hline (b) & 88 & $6 \cdot 2$ & 30 & 70 & $6 \cdot 5$ & 28 & 126 & 95 & 107 & 0.8 & Yes & $1 \cdot 0$ & Yes & 80 & $7 \cdot 5$ & $9 \cdot 0$ & 83 \\
\hline (c) & 70 & 6.0 & 42 & 65 & $6 \cdot 7$ & 32 & 107 & 90 & 131 & $1 \cdot 2$ & Yes & $1 \cdot 7$ & Yes & 71 & ND & ND & ND \\
\hline
\end{tabular}

platelets in PRP was examined by transmission electron microscopy according to standard techniques (Cawley and Hayhoe, 1973).

\section{Results}

PLATELET AGGREGATION

The results of measurements of platelet aggregation to ADP, collagen, adrenaline, and ristocetin are set out in Tables 1 and 2. Patient platelet responses were compared with the corresponding control by expressing the patient/control measurement as a percentage.

\section{$A D P$}

With the exception of patient AF on one of the three occasions studied, the aggregation (Vmax) of HCL platelets closely resembled that of the control. In patient AF, the low Vmax ( $26 \%$ of control) became comparable with that of the control after splenectomy. In contrast, the $\mathrm{Km}$ concentration of ADP varied between $26 \%$ and $203 \%$ of the control. However, the range of $\mathrm{Km}$ (ADP) values for $\mathrm{HCL}$ patients as a group was similar to that for the controls. In general, there was no clear relationship between splenectomy and either Vmax or $\mathrm{Km}$.

\section{Collagen}

The lag time was markedly prolonged $(160 \%$ of control) in two patients (WE and AF) and in patient AF returned towards the control value after splenectomy. In the other six patients, there was no convincing abnormality in lag time (mean $100 \%$; range $79-125 \%)$

The two patients with a prolonged lag time (WE and AF) also showed the lowest aggregation rate and Tmax; in patient AF these values again improved after splenectomy. In the remaining six patients the aggregation rate and Tmax varied considerably (for rate, mean $127 \%$, range $69-182 \%$, for Tmax, mean $110 \%$, range $65-143 \%$ ).

\section{Adrenaline}

The rate of adrenaline-induced aggregation was reduced in six (mean $75 \%$, range $50-97 \%$ ) of the seven patients tested. A high rate of aggregation $(136 \%)$ was observed in one patient $(\mathrm{AB})$.

The lowest rate of adrenaline-induced aggregation was observed in patient AF, the only patient in whom platelet release to stimulation with adrenaline was not observed at a time when it was present in the control. In two other patients with apparently absent release, no release was observed in the control, and its absence could not, therefore, be unequivocally related to an abnormality of the patients' platelets.

\section{Ristocetin}

The platelet response to ristocetin was markedly reduced in three patients (FW $34 \%$, WE $25 \%$, and AF $21 \%$ ). In patient $\mathrm{AF}$, ristocetin response was seen to improve after splenectomy. The response in the other five patients, tested once only, varied greatly (mean $109 \%$, range $70-178 \%$ ) (Table 2 ).

\section{Thrombin}

The platelet response to thrombin was measured in three patients (PS, FW, and AB), and aggregation rates of $100 \%, 100 \%$, and $121 \%$ of the control were obtained. The plasma thrombin clotting time, as indicated by a sudden deflection of the recorder pen after aggregation, was similar in patient and control plasmas.

ACCUMULATION, STORAGE, AND RELEASE OH 5-HT

The results for six patients and for three control subjects are set out in Fig. 1 and Table 3; the two patients (HD and FB) on low-dose steroid were 
Table 3 Platelet granule storage and release of 5-HT

\begin{tabular}{|c|c|c|c|c|}
\hline & \multirow[t]{2}{*}{ Case } & \multicolumn{2}{|c|}{ Granule storage capacity* } & \multirow{2}{*}{$\begin{array}{l}\% \\
\text { Release } \dagger\end{array}$} \\
\hline & & $\begin{array}{l}\text { nmol } 5-H T / 10^{8} \\
\text { platelets }\end{array}$ & $\begin{array}{l}\% \text { Control } \\
\text { mean }\end{array}$ & \\
\hline Normal controls & $\begin{array}{l}\text { CP } \\
\text { JC } \\
\text { MZ }\end{array}$ & $\begin{array}{l}1.475 \\
1.325 \\
1 \cdot 250\end{array}$ & $\begin{array}{r}109 \\
98 \\
93\end{array}$ & $\begin{array}{l}105 \\
100 \\
104\end{array}$ \\
\hline HCL patients & $\begin{array}{l}\text { AB } \\
\text { PS } \\
\text { FW } \\
\text { LH } \\
\text { WE } \\
\text { AF }\end{array}$ & $\begin{array}{l}1.50 \\
1.175 \\
0.95 \\
0.75 \\
0.675 \\
0.50\end{array}$ & $\begin{array}{r}111 \\
87 \\
70 \\
56 \\
50 \\
37\end{array}$ & $\begin{array}{r}111 \\
105 \\
86 \\
93 \\
81 \\
71\end{array}$ \\
\hline
\end{tabular}

* Granule storage capacity calculated as the difference between the radioactivity of non-reserpinised and reserpinised platelets at 120 minutes' incubation of PRP with $\left\{2^{-14} \mathrm{C}\right\}$ 5-HT (see text and Fig. 1). †Release calculated as percentage loss of granule stores estimated at time of addition of thrombin (see text and Fig. 1)

excluded from this part of the study. In both patients and controls, an increase in platelet radioactivity with time of incubation was observed, reaching a plateau by 90 minutes (Fig. 1), always leaving an excess of 5-HT in plasma. At this point the radioactivity of non-reserpinised platelets is distributed between the saturated platelet granular, and the cytoplasmic, non-granular, compartments (Costa et al., 1977). In all instances, the accumulation of radioactivity by platelets was markedly reduced by the presence of reserpine at a concentration which selectively blocks granule uptake (Da Prada and Pletscher, 1968; Weiss et al., 1974; Reimers et al., 1977) (Fig. 1). The radioactivity in reserpinised platelets represents 5-HT and its metabolites in the cytoplasmic, non-granular, compartment where the concentration gradient across the platelet membrane is maintained by the continued activity of a 5-HT membrane transport mechanism. Addition of imipramine at 90 minutes (at a concentration which selectively and completely blocks active 5-HT uptake by platelets (Tuomisto, 1974; Reimers et al., 1977)) resulted in a partial loss of radioactivity from both reserpinised and nonreserpinised platelets (Fig. 1). As can be seen from Fig. 1, this loss was more pronounced during the first 30 minutes post-imipramine than during the subsequent 30 minutes. In addition, the rate of loss of radioactivity in the first $\mathbf{3 0}$ minutes was slightly greater for reserpinised than for non-reserpinised platelets. This difference is presumably the result of more radioactivity being present in the extracellular and the cytoplasmic, non-granular compartments in the presence of blocked granule uptake. During the 30-60 minutes post-imipramine incubation, nonreserpinised platelets continued to lose significant amounts of radioactivity, while loss from reserpinised platelets was negligible. This continued loss of radioactivity from non-reserpinised platelets probably reflects the loss of 5-HT from saturated granules by dissociation and slow diffusion from platelets when active uptake is blocked by imipramine. Therefore, for calculating granule storage capacity (the difference between the radioactivity of non-reserpinised and reserpinsed platelets, Table 3), the 30 minutes post-imipramine incubation time was selected, both to minimise the error from granule 5-HT loss and to allow for outflow of most cytoplasmic, non-granular radioactivity since, as explained above, cytoplasmic radioactivity is not strictly comparable in reserpinised and non-reserpinised platelets.

Granule storage capacity for 5-HT was very similar in the three normal controls (mean 1.35 $\mathrm{nmol} / 1 \mathrm{C}^{8}$ platelets, range $1 \cdot 25-1 \cdot 475$ ). In five of the six HCL patients, granule storage capacity was variably reduced (mean $0.81 \mathrm{nmol} / 10^{8}$ platelets, range $0 \cdot 5-1 \cdot 175 ; 37-87 \%$ of the control mean).

5-HT release was estimated 10 minutes after stimulation by thrombin; any reuptake of released 5-HT during this period was blocked by the continued presence of imipramine. The released radioactivity was then expressed as a percentage of estimated granular 5-HT at the time of thrombin addition (150 minutes). The radioactivity remaining in platelets after complete granule release mainly represents the amount of metabolites accumulated in the platelet cytoplasm during the incubation (Pletscher et al., 1968). (This approximates to the post-imipramine radioactivity of reserpinised platelets.) The release of granular 5-HT from HCL platelets on stimulation with high concentrations of thrombin was normal or slightly reduced in parallel with the reduction in the granule storage capacity (Table 3).

Compared with the two normal controls (1.5 and $1.8 \mathrm{mg}$ protein $/ 10^{9}$ platelets), platelet pellets from the two HCL patients with the most reduced storage pool capacity (AF and WE) contained almost twice as much protein per unit cell number $(2.9$ and 2.9 $\mathrm{mg}$ protein $/ 10^{9}$ platelets). This difference was probably attributable to red cell contamination of the PRP preparations from these two patients. Since the volume of a single red cell is approximately 10 times that of a normal platelet and since red cell contamination did not exceed $10 \%$, we conclude that HCL platelets were not smaller than normal. Also, in all patients, the platelets appeared to be of normal size by phase-contrast microscopy.

\section{BLEEDING TIME}

The bleeding times are listed in Table 1. In one patient (WE) the bleeding time was prolonged (15 minutes), but in all other patients tested it was within the normal range for the method (2-3-9.5 minutes). 


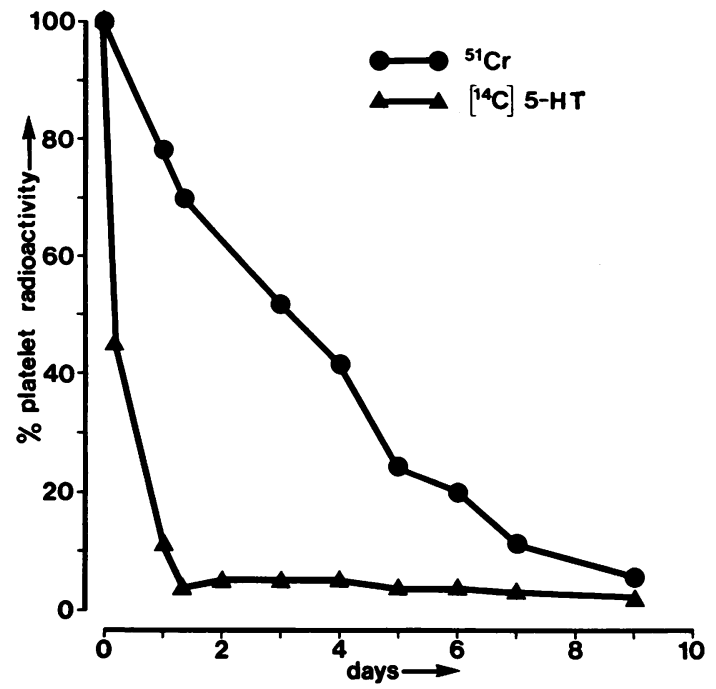

Fig. 2 Disappearance of ${ }^{51} \mathrm{Cr}$-labelled platelets and $\left\{2-{ }^{14} C\right\} 5-H T$ radioactivity from the circulation in $H C L$ patient $W E$.

PLATELET SURVIVAL

${ }^{51} \mathrm{Cr}$-labelling of platelets from a patient (WE) with a marked reduction in 5-HT storage capacity showed a platelet survival time of $7 \cdot 4$ days (Fig. 2) (normal range 8-11 days (Harker and Slichter, 1972)). This relatively normal result suggests that any contribution of splenomegaly to the patient's thrombocytopenia was a consequence of sequestration rather than enhanced platelet destruction. This finding is in keeping with the general concept that the main contribution of splenomegaly to the cytopenia of the disease is the result of splenic pooling (Lewis et al., 1977). The result also argues against significant platelet destruction by other mechanisms such as immune injury (in a second patient (AF) with an even more marked storage granule defect, no platelet antibodies were detectable by a variety of methods).

Parallel measurements of ${ }^{14} \mathrm{C}$ radioactivity in PRP showed a rapid, early fall, so that at 36 hours and thereafter about $5 \%$ of the activity recovered 1 hour after the infusion of labelled 5-HT was detectable (Fig. 2). This result was in marked contrast to our findings in a group of non-leukaemic patients in whom, after an initial marked fall during the first 24 hours, appreciable quantities of 5-HT were retained and gradually lost from the circulation over a period of five to nine days (Paton et al., 1978).

\section{ELECTRON MICROSCOPY}

Examination of a large number of sectioned platelets from patient AF showed a marked reduction of very dense bodies, but no attempt was made to quantitate this deficiency. With the exception of occasional unusually large granules, platelet ultrastructure was otherwise unremarkable.

\section{Discussion}

The aim of the present study was to assess platelet function in HCL in a quantitative way. Such a study requires particular attention to technical aspects of in-vitro tests (Packham et al., 1976) and the inclusion of adequate controls.

In all our in-vitro platelet function studies, platelets from each patient were examined together with normal control platelets handled in a similar way. In order to minimise preparative artefacts (Sixma, 1976), no attempt was made to wash or concentrate platelets. In the aggregation studies, to make controls strictly comparable with the patients who were frequently thrombocytopenic, normal PRP was diluted to the required platelet concentration with autologous PPP (Zucker, 1970).

Our aggregation studies showed convincing abnormalities in at least two (AF and WE) of the eight HCL patients, and these abnormalities involved more than one aggregating agent. These two patients had the longest bleeding times of those tested but, like all our HCL patients, did not have a significant clinical bleeding problem. In the only patient tested before and after splenectomy, there was some improvement in aggregation tests after splenectomy. However, in the group of HCL patients as a whole, there was no clear relationship between in-vitro platelet aggregation and either splenectomy or platelet count.

Previous studies specifically concerned with platelet function in HCL have shown that the platelet response to adrenaline is abnormal in a high proportion of patients. However, there has been no agreement about platelet responses to other aggregating agents, although abnormalities in both primary, release-independent and secondary, releasedependent platelet aggregation have been noted (Levine and Katayama, 1975; Feiner et al., 1978; Golomb, 1978; Golomb et al., 1978). Our aggregation studies showed little evidence of an abnormal primary response to ADP but revealed a consistent slight reduction in the primary response to adrenaline. In addition, in at least two patients, there was a general reduction in platelet responses to all stimuli which partly or wholly depend on platelet granule secretion. This indicated the possibility of a storage pool or release defect and prompted further investigation with labelled 5-HT.

Our studies of accumulation, storage, and release of $\left\{{ }^{14} \mathrm{C}\right\}$ 5-HT showed that platelet granule 5-HT 
storage capacity was reduced in most HCL patients, and estimation of total platelet protein indicated that this was not simply due to reduced platelet size. Although such a defect has not previously been described in HCL, a similar type of platelet dysfunction, involving reduced 5-HT storage and a parallel reduction of granular adenosine nucleotides, has been demonstrated in a number of disorders (Boullin and O'Brien, 1971; Hardisty et al., 1972; Weiss et al., 1974; Pareti et al., 1976), including a variety of leukaemias (Hardisty and Stacey, 1957; Cowan et al., 1975; Gerrard et al., 1978).

The present study provides no direct evidence concerning the underlying mechanism or cause of the storage pool defect (SPD) in HCL. However, our data provide some indirect evidence of possible relevance. For example, the platelet dysfunction clearly does not bear a simple relationship to thrombocytopenia since we, and others (Levine and Katayama, 1975; Golomb et al., 1978), have observed platelet abnormalities in patients with a normal platelet count. Moreover, although we observed some improvement of platelet aggregation in one patient after splenectomy, and a similar observation has been reported in one other patient (Feiner et al., 1978), splenomegaly cannot be the general underlying cause of the platelet defect since some of our splenectomised patients showed abnormal platelet storage of 5-HT. For the same reason, splenic sequestration of platelets seems an unlikely general cause of the platelet defect. Therefore, since all our HCL patients ran a chronic course uncomplicated at the time of study by any of the factors known to predispose to a platelet SPD acquired in the circulation (Zahavi and Marder, 1974; Pareti et al., 1976), we suggest that abnormal platelet production in the marrow is of prime importance in the SPD of HCL. In view of the now overwhelming evidence for the B-cell nature of the disease (Catovsky, 1977; Golde et al., 1977; Burns et al., 1978), it seems highly unlikely that this defective platelet production can be ascribed to a direct involvement of the megakaryocytic series in the underlying cell proliferation. It seems more likely that the SPD of the platelets in HCL is attributable to the extensive fibrosis and/or hairy cell infiltration of the bone marrow that are so characteristic of the disease.

The $\left\{2-{ }^{14} \mathrm{C}\right\}$ 5-HT infusion was approved by the Radioisotopes Advisory Panel of the DHSS, and informed consent was obtained from the patient. We are grateful to Dr S. M. Rajah (Seacroft Hospital, Leeds) for ${ }^{51} \mathrm{Cr}$ platelet labelling and for the investigation of anti-platelet antibodies. We are also grateful to Drs B. E. Roberts, J. A. Child
(General Infirmary, Leeds), and K. Hunt (Bradford Royal Infirmary) for allowing us to study their patients. We should like to thank Mrs A. Spencer for skilful technical assistance, $\mathrm{Mr} \mathrm{H}$. Starkey for preparation of the figures for publication, and Miss H. Collingwood and Miss K. Woolley for typing the manuscript.

\section{References}

Aster, R. H., and Jandl, J. H. (1964). Platelet sequestration in man. I. Methods. Journal of Clinical Investigation, 43, 843-855.

Boullin, D. J., and O'Brien, R. A. (1971). Abnormalities of 5-hydroxytryptamine uptake and binding by blood platelets from children with Down's syndrome. Journal of Physiology, 212, 287-297.

Bouroncle, B. A., Wiseman, B. K., and Doan, C. A. (1958). Leukemic reticuloendotheliosis. Blood, 13, 609-630.

Brecher, G., and Cronkite, E. P. (1950). Morphology and enumeration of human blood platelets. Journal of Applied Physiology, 3, 365-377.

Burns, G. F., Cawley, J. C., Higgy, K. E., Barker, C. R., Edwards, M., Rees, J. K. H., and Hayhoe, F. G. J. (1978). Hairy-cell leukaemia: a B-cell neoplasm with a severe deficiency of circulating normal B lymphocytes. Leukaemia Research, 2, 33-40.

Catovsky, D. (1977). Hairy-cell leukaemia and prolymphocytic leukaemia. Clinics in Haematology, 6, 245-268.

Cawley, J. C., and Hayhoe, F. G. J. (1973). Ultrastructure of Haemic Cells. W. B. Saunders, London.

Costa, J. L., Murphy, D. L., and Kafka, M. S. (1977). Demonstration and evaluation of apparent cytoplasmic and vesicular serotonin compartments in human platelets. Biochemical Pharmacology, 26, 517-521.

Cowan, D. H., Graham, R. J., Jr., and Baunach, D. (1975). The platelet defect in leukemia: platelet ultrastructure, adenine nucleotide metabolism, and the release reaction. Journal of Clinical Investigation, 56, 188-200.

Da Prada, M., and Pletscher, A. (1968). Isolated 5-hydroxytryptamine organelles of rabbit blood platelets: physiological properties and drug-induced changes. British Journal of Pharmacology, 34, 591-597.

Feiner, A. S., Myers, A. M. Jr., and Moore, G. E. (1978). Leukemic reticuloendotheliosis. Loss of platelet defect after splenectomy. Journal of the American Medical Association, 240, 238-240.

Gerrard, J. M., Stoddard, S. F., Shapiro, R. S., Coccia, P. F., Ramsay, N. K. C., Nesbit, M. F., Rao, G. H. R., Krivit, W., and White, J. G. (1978). Platelet storage pool deficiency and prostaglandin synthesis in chronic granulocytic leukaemia. British Journal of Haematology, 40, 597-607.

Golde, D. W., Stevens, R. H., Quan, S. G., and Saxon, A. (1977). Immunoglobin synthesis in hairy cell leukaemia. British Journal of Haematology, 35, 359-365.

Golomb, H. M. (1978). Hairy cell leukemia: an unusual lymphoproliferative disease. A study of 24 patients. Cancer, 42, 946-956. 
Golomb, H. M., Vardiman, J., Sweet, D. L., Jr., Simon, D., and Variakojis, D. (1978). Hairy cell leukaemia: evidence for the existence of a spectrum of functional characteristics. British Journal of Haematology, 38, 161-170.

Hardisty, R. M., Mills, D. C. B., and Ketsa-ard, K. (1972). The platelet defect associated with albinism. British Journal of Haematology, 23, 679-692.

Hardisty, R. M., and Stacey, R. S. (1957). Platelet 5-hydroxytryptamine (HT) in disorders of the blood. British Journal of Haematology, 3, 292-298.

Harker, L. A., and Slichter, S. J. (1972). Platelet and fibrinogen consumption in man. New England Journal of Medicine, 287, 999-1005.

Herberg, R. J. (1960). Determination of carbon-14 and tritium in blood and other whole tissues. Analytical Chemistry, 32, 42-46.

Hess, H. H., Lees, M. B., and Derr, J. E. (1978). A linear Lowry-Folin assay for both water-soluble and sodium dodecyl sulfate-solubilized proteins. Analytical Biochemistry, 85, 295-300.

Jansen, J., Hermans, J., Remme, J., den Ottolander, G. L., and Cardoza, P. L. (1978). Hairy cell leukaemia: clinical features and $\epsilon$ ffect of splenectomy. Scandinavian Journal of Haematology, 21, 60-71.

Katayama, I., and Finkel, H. E. (1974). Leukemic reticuloendotheliosis. A clinicopathologic study with review of the literature. American Journal of Medicine, 57, 115-126.

Levine, P. H., and Katayama, I. (1975). The platelet in leukemic reticuloendotheliosis. Functional and morphological evidence of a qualitative disorder. Cancer, 36, 1353-1358.

Lewis, S. M., Catovsky, D., Hows, J. M., and Ardalan, B. (1977). Splenic red cell pooling in hairy cell leukaemia. British Journal of Haematology, 35, 351-357.

Mielke, C. H., Jr., Kaneshiro, M. M., Maher, I. A., Weiner, J. M., and Rapaport, S. I. (1969). The standardized normal Ivy bleeding time and its prolongation by aspirin. Blood, 34, 204-215.

Packham, M. A., Kinlough-Rathbone, R. L., and Mustard, J. F. (1976). Aggregation and agglutination. In Platelet Function Testing, p. 66. DHEW Publication No. (NIH) 78-1087. US Department of Health, Education and Welfare.

Pareti, F. I., Capitano, A., and Mannucci, P. M. (1976). Acquired storage pool disease in platelets during dis- seminated intravascular coagulation. Blood, 48, 511-515.

Paton, R. C., Rajah, S. M., Menys, V. C., and McNicol, G. P. (1979). Double labelling of platelets with ${ }^{51} \mathrm{Cr}$ and $\left\{{ }^{14} \mathrm{C}\right\} 5-\mathrm{HT}$ in the measurement of platelet survival. Proceedings of VIIth International Congress on Thrombosis and Haemostasis. Thrombosis and Haemostasis, in press.

Pletscher, A., Da Prada, M., and Tranzer, J. P. (1968). Metabolism, subcellular transport and storage of 5-hydroxytryptamine in blood platelets. Annales Medicinae Experimentalis et Biolologiae Fenniae, 46, 399-406.

Reimers, H. J., Allen, D. J., Cazenave, J. P., Feuerstein, I. A., and Mustard, J. F. (1977). Serotonin transport and storage in rabbit blood platelets-the effects of reserpine and imipramine. Biochemical Pharmacology, 26, 1645-1655.

Sebahoun, G., Boufette, P., and Flandrin, G. (1978). Hairy cell leukemia. Leukemia Research, 2, 187-195.

Sixma, J. J. (1976). Platelet isolation. In Platelet Function Testing, p. 34. DHEW Publication No. (NIH) 78-1087. US Department of Health, Education and Welfare.

Skoza, L., Zucker, M. B., Jerushalmy, Z., and Grant, R. (1967). Kinetic studies of platelet aggregation induced by adenosine diphosphate and its inhibition by chelating agents, guanidino compounds, and adenosine. Thrombosis et Diathesis Haemorrhagica, 18, 713-725.

Tuomisto, J. (1974). A new modification for studying 5-HT uptake by blood platelets: a re-evaluation of tricyclic antidepressants as uptake inhibitors. Journal of Pharmacy and Pharmacology, 26, 92-100.

Weiss, H. J., Tschopp, T. B., Rogers, J., and Brand, H. (1974). Studies of platelet 5-hydroxytryptamine (serotonin) in storage pool disease and albinism. Journal of Clinical Investigation, 54, 421-432.

Zahavi, J., and Marder, V. J. (1974). Acquired 'storage pool disease' of platelets associated with circulating antiplatelet antibodies. American Journal of Medicine, 56, 883-890.

Zucker, M. B. (1970) Tests of platelet adhesion, aggregation and release. Thrombosis et Diathesis Haemorrhagica, Supplement, 42, 1-12.

Requests for reprints to: Dr M. Zuzel, University Department of Medicine, Martin Wing, General Infirmary, Leeds LS1 3EX, UK. 